\title{
Learning Activeness Affects the Ability to Understand Students' Mathematical Concepts Using Discovery Learning Model
}

\author{
Dian Setyo Budi \\ Pendidikan Guru Sekolah Dasar, FakultasKeguruan dan Ilmu Pendidikan, UniversitasMuria Kudus, Indonesia \\ e-mail:dianb8649@gmail.com
}

Henry Suryo Bintoro

Pendidikan Matematika, FakultasKeguruan dan Ilmu Pendidikan, UniversitasMuria Kudus, Indonesia

e-mail: henry.suryo@umk.ac.id

\author{
Ratri Rahayu \\ Pendidikan Matematika, FakultasKeguruan dan Ilmu Pendidikan, UniversitasMuria Kudus, Indonesia \\ e-mail:ratri.rahayu@umk.ac.id
}

\author{
A R T I C L E I N F O \\ Article history: \\ 1 Mei 2020 Received in \\ revised form \\ 11 Juni 2020 \\ Accepted 10 Juli 2020 \\ Available online 25 Agustus \\ 2020 \\ Kata Kunci: \\ KeaktifanBelajar, \\ Discovery Learning, \\ PemahamanKonsep. \\ Keywords: \\ Activeness in learning, \\ Discovery Learning, \\ Understanding Concept
}

\begin{abstract}
A B S T R A K
Keaktifan belajar merupakan bekal yang harus dimiliki oleh setiap siswa dalam belajar matematika karena keaktifan belajar berpengaruh terhadap kemampuan pemahamn konsep yang didapatkan siswa. Masalah yang ditemukan oleh peneliti waktu observasi rendahnya keaktifan belajar siswa sehingga kemampuan pemahamn konsep yang didapatkan siswa juga masih rendah dalam pembelajaran matematika. Tujuan penelitian ini untuk menganalisis seberapa besar pengaruh keaktifan belajar terhadap kemampuan pemahaman konsep matematis dengan menggunakan model discovery learning. Penelitian ini merupakan peneltian kuantitatif eksperimen dengan tipe the one-shot case study desain. Sampel dalam penelitian ini yaitu 40 siswa kelas V SD. Teknik pengumpulan data terdiri dari tes tertulis kemampuan pemahaman konsep dan observasi keaktifan belajar. Teknik analisis data dalam penelitian ini meliputi uji regresi linier sederhana. Berdasarkan hasil penelitian menunjukan bahwa Keaktifan belajar berpengaruh secara positif dan signifikan sebesar 69,8\% terhadap kemampuan pemahaman konsep matematis dengan menggunakan model discovery learning. Artinya jika semakin tinggi keaktifan belajar siswa maka semakin tinggi pula hasil pemahaman konsep matematis siswa.
\end{abstract}

\section{A B S T R A C T}

Learning activeness is a provision that must be possessed by every student in learning mathematics because active learning affects the conceptual ability of students. The problem that was found by the researcher during the observation time was the low student learning activeness so that the students' ability to understand concepts was still low in learning mathematics. The purpose of this study was to analyze how much influence active learning has on the ability to understand mathematical concepts using discovery learning models. This research is a quantitative experiment with the one-shot case study design type. The sample in this study were 40 students of grade V SD. Data collection techniques consisted of a written test of the ability to understand concepts and observation of learning activeness. The data analysis technique in this study includes a simple linear regression test. Based on the research results, it shows that learning activeness has a positive and significant effect of $69.8 \%$ on the ability to understand mathematical concepts using discovery learning models. This means that if the higher the student's learning activeness, the higher the results of understanding the students' mathematical concepts.

\section{Introduction}

One way to improve quality education is through the application of an appropriate curriculum. In education, the current curriculum used is the 2013 Curriculum education unit. According to Law Number 20 of 2013 , the curriculum is a set of plans and arrangements regarding the objectives, content, and learning materials and methods used as guidelines for the implementation of learning activities to achieve educational goals(Triwiyanto, 2015). The curriculum is a set of plans and arrangements regarding the content and learning materials and is used as a guide for implementing teaching and learning activities(Hambalik, 2015). In 2013 curriculum, the learning process requires students to always be active, creative and innovative. Learning is not teacher-centered but learning must be student-centered so that students are more active in learning.

Learning activeness is the most important thing in mathematics learning because active learning affects student's achievement. Learning activeness is said to be successful when there is a reciprocal relationship between students and teachers. In the learning process, if students are less active, students' understanding of 
concepts is also low. One of the efforts to increase learning activeness is by providing student learning motivation. Learning activeness is the involvement of students in the learning process with the aim of having success in active learning(Lestari \& Yudhanegara, 2015). Active learning is learning in which students learn mathematics actively develops concepts and a variety of mathematical abilities through interactions with the environment outside themselves and with themselves(Hendriana et al., 2017). Active learning cannot be separated when the teaching and learning process takes place because active learning will foster good mental health for children and be able to express all ideas in the learning process and foster children's creativity in learning. Learning activeness can improve student learning outcomes(Duwit, 2016). In addition to learning outcomes that increase student activity, it is also able to make students' understanding broad or develop. The high level of student activity in science learning will cause student understanding to be broader and student learning outcomes will increase(Samadhi \& Riastini, 2017).

The activeness of students during the learning process greatly affects their ability to understand concepts. Concept understanding is the ability of students to understand and absorb a material given by the teacher so that they are able to solve problems. Understanding of mathematical concepts is a student's cognitive ability in understanding mathematical materials which are summarized in expressing ideas, processing information, and explaining in their own words through the learning process to solve problems according to rules based on concepts(Febriyanto et al., 2018). Understanding of mathematical concepts is the knowledge of students in absorbing material about concepts, principles, procedures and students' ability to use solving strategies to a problem presented(Junitasari \& Hayati, 2019). The students, who understand the concept well, can overcome problems given by the teacher with their oen way. Their achievement in improving conceptual understanding is in accordance with their activeness in learning process. It has positive and significant effect toward learning achievement (Maulida et al., 2018).

The reality is not in accordance with expectations. It seems that the activeness of students in learning is still low so that students are not able to participate in learning optimally. Students do not seem to be active during the learning process, until now the learning process is still centered on the teacher even though the educational standard is expected in the student-centered learning process. Based on this condition, the understanding that students gain is limited because students only receive material from the teacher, even though the students' ability is able to develop about the material. This is in accordance with the problems that exist in SD Kuwawur 02 which the researcher got when doing observations shows that student learning activity is still low due to the lack of interest and enthusiasm of students in learning mathematics. This causes students to be less active during the mathematics learning process so that students' understanding of concepts is still low. . In addition, the learning process is still teacher-centered, causing students to have less courage to ask or answer questions when they get problems. In conducting interviews, researchers also strengthen data through the results of preliminary studies showing student learning activeness has an average of 50.16 with a predicate of needing guidance and for understanding the concept has an average of 57.95 with a predicate of needing guidance. From these results, it can be seen that there needs to increase student learning activeness. There are problems that occur in these schools, it is necessary to provide solutions or handling so that the problems are immediately recognized. After the problems can be resolved by providing solutions, it is expected that students will be active in learning mathematics so that the ability to understand concepts that students get is also increased.

The problems found by researchers at SD Kuwawur 02 must be overcome with the right solution. The solution given by the researcher is in the form of applying a model that is able to make students feel pleasant in learning so that it makes students active or have the courage to have an opinion. Researchers provide a discovery learning model where this model is in the implementation of students learn independently so as to give full confidence to students to find a concept. To which in the process unconsciously, it makes students active in the concept discovery process. The application of the discovery learning model aims to change the passive way of learning to be active and change the learning process that was originally teacher-centered to make the learning process student-centered. The use of discovery learning models can improve student learning activities(Jayadiningrat et al., 2019).Providing solutions with the application of the discovery learning model is very appropriate because it can make students active in the learning process.

By providing solutions, it is expected an innovative and fun learning process. When students feel happy in the learning process, they easily accept the material presented by the teacher because students do not feel burdened and scare of the teachers, and causing students to be active in answering or asking questions to the teacher. The application of discovery learning model is a very appropriate model to increase student activeness because this model emphasizes students to learn independently and find new ideas in the concept discovery process so that the knowledge gained is easy to remember by students. Discovery Learning is a learning process that is not given as a whole but involves students to organize, develop knowledge and skills for problem solving(Yuliana, 2018). With the use of the Discovery learning model, it can make students active and creative. The use of the Discovery Learning model is a series of learning processes that involve students learning actively in order to achieve the expected learning goals, by means of students finding knowledge independently and 
attitudes as well as skills toward questions given by the teacher(Sari et al., 2017). The Discovery Learning learning model has many advantages such as students being able to understand concepts independently and students being active in the learning process(Sumaryati et al., 2018).The advantage of the Discovery Learning learning model is that students are active in learning activities, because they think and use their abilities to find the final result(Kristian, 2017). Student activeness in learning activities provides a special passion for students during the learning process. A good learning process provides good final results such as increasing understanding of concepts and good student achievement. Learning Discovery Learning based on animation media has an effect on learning outcomes(Putra. et al., 2020). Besides having many advantages, the discovery learning model also has stages in its implementation to make learning structured and run coherently so that it is in accordance with the expected learning objectives. The steps in the discovery learning model according to the theory are as follows(Cahyo, 2013). The first step is stimulation, at this stage the teacher provides stimulation in the form of questions by asking problems or asking students to read or listen to descriptions that cause problems. The second step is the Problem Statement at the stage where students identify the problem and find the relevance of data sources in order to formulate problems. In the third step, data collection at this stage, the teacher gives freedom to students to find as much information as possible to answer the hypothesis. The fourth step is Data Processing. In this stage, students process data from the data obtained in the previous stage to prove new concepts or knowledge. The fifth step of verification at this stage the teacher provides opportunities for students to find concepts, theories, rules or understanding through the examples they encounter in life. The final step of Generalization, in this last stage, students draw conclusions from the problems given by the teacher and get a new concept.

The learning process of Discovery Learning students becomes more active in the learning process and students more easily accept the material presented by the teacher(Rahmayani et al., 2019). The use of the Discovery Learning model is essential in developing mathematical communication skills and increasing student learning activeness in learning mathematics(Maulida et al., 2018). The application of the Discovery Learning model is also able to increase student learning activeness in learning mathematics(Putri, 2018).

Based on the description of the problems above, the researcher conducted a quantitative study entitled "The Effect of Learning Activeness on Students' Understanding Ability of Mathematical Concepts using Discovery Learning Model". The purpose of this study is to determine how much learning activeness affects students' ability to understand mathematical concepts.

\section{Method}

This research is a quantitative research type of experiment with the Pre-Experimental method. The design used is the one-shot case study design. This design is used by researchers to analyze learning activeness towards understanding concepts. In this study, the researcher observed learning activeness using Discovery Learning model during the learning process of understanding the concept. Population is a generalization area consisting of objects or subjects that have certain qualities and characteristics determined by the researcher(Sugiyono, 2010). In this study, the population used was all students of SD Kuwawur 02, totaling 186 students. The sample used is the random sampling technique with random sample selection regardless of strata or by way of drawing. The sample chosen was the fifth-grade students of SD Kuwawur 02, totaling 40 students. Data collection techniques were in the form of tests and non-tests. The test is in the form of a description of the ability to understand the concept given at the end of the lesson in the form of a post-test, while the non-test is in the form of an observation sheet that takes data through observations while the learning takes place. The data analysis technique in this study used simple linear regression test analysis to determine how much effect learning activeness has on the ability to understand concepts by using discovery learning models. The regression test stages are (1) determining the regression equation; (2) the regression equation linearity significance test, (3) the regression equation coefficient significance test; (4) determining the correlation coefficient and the correlation coefficient significance test; (5) determining the coefficient of determination. These steps aim to determine how much the percentage effect of active learning on the ability to understand mathematical concepts.

\section{Result and Discussion}

The research was carried out at SD Kuwawur 02 for the 2019/2020 school year. This study was conducted to determine the effect of learning activeness on students' ability to understand mathematical concepts by using discovery learning models. The data obtained through observations conducted during the concept understanding mathematics lesson, before the regression test, the data is described first. Descriptive data from the observations can be seen in table 1 . 
Table 1. Descriptive Value of Learning Activeness

\begin{tabular}{cc}
\hline Descriptive Data & Score \\
\hline The highest score & 82,29 \\
Lowest Value & 54,69 \\
Average & 72,01 \\
Total Students Completed & 28 \\
Number of Incomplete Students & 12 \\
\hline
\end{tabular}

Based on table 1, it can be concluded that students learning activeness has an average of 72.01 with sufficient criteria. Learning activeness is carried out by means of observation using the learning activeness observation sheet. Observation takes place from the first meeting until the fourth or last meeting. It is carried out when the learning process takes place using the Discovery Learning model. The observation results in each indicator can be seen in figure 1 .

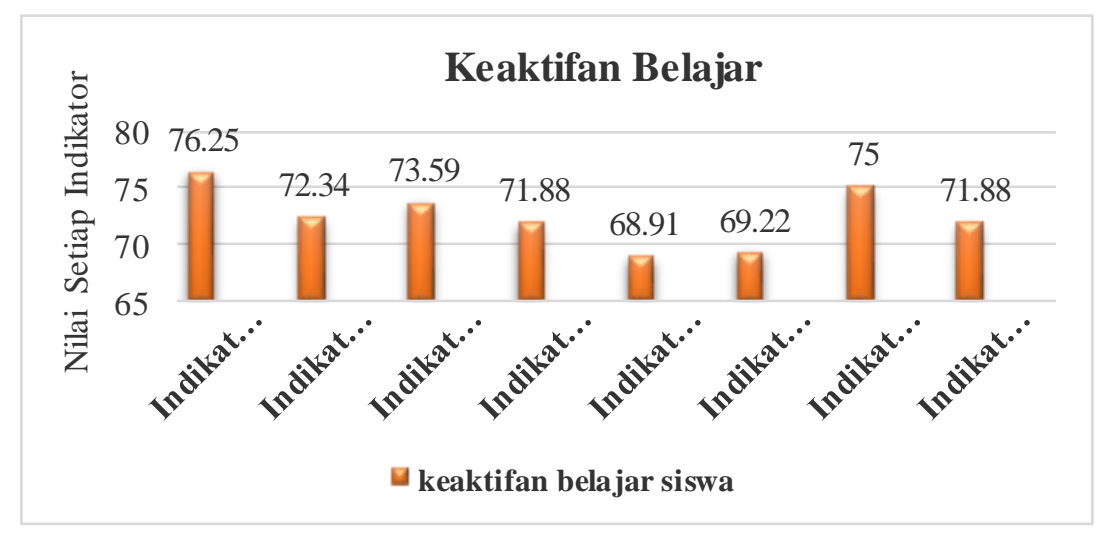

Figure 1. Results of Learning Activeness Indicators

Based on Figure 1, it can be seen the results of student learning activeness in participating in mathematics learning for each indicator. The first indicator which is expressing an opinion gets a value of 76.25 which is in the sufficient category. The second indicator that is asking questions gets a value of 72.34 is included in the sufficient category. The third indicator which is responding to other people's opinions gets a value of 73.59 which is in the sufficient category. The fourth indicator, doing the task well, gets a value of 71.88 , which is in the sufficient category. The fifth indicator, which is participating in carrying out their learning assignments, gets a value of 68.91, which falls into the category of needing guidance. The sixth indicator which read as being involved in problem solving activities getting a value of 69.22 also falls into the category of needing guidance. The seventh indicator, which is carrying out a group discussion, gets a score of 75 , which is in the sufficient category. While the last indicator, which is dare to appear in front of the class, getting a score of 71.88 is in enough category. From these results, it can be seen that the fifth indicator has the lowest results. In the fifth indicator which is students are able to carry out their learning assignments and seek for information from other sources or other references. It is due to students have not been able to find information from other sources and students are still depent on textbooks or worksheets. Students are still not able to carry out their learning tasks optimally because they are still afraid to try new things. Meanwhile, student learning activeness in the first indicator has the highest value. In the first indicator, students are able to express their opinions during group discussions gets the highest results because students listen when the teacher explains the material, so that students feel that they understand the material presented by the teacher and the understanding of the students obtained is able to make students confident in the learning process. Learning becomes interesting so that students are able to practice with their groups and talk or provide input about their ideas in the group. During the presentation process, students were very enthusiastic about asking questions so that it made them active in answering questions because they were equipped with good concept understanding skills. Therefore, learning becomes alive and active because of the reciprocal relationship between teachers and students and students and their friends.

This regression test is used to determine the effect of student learning activeness on the ability to understand mathematical concepts using the Discovery Learning Model. The regression test was analyzed using the SPSS application. The results presented in this research are in the form of an SPSS Output table. The regression test steps are as follows. 
The first step is to determine the Simple Linear Regression Equation, $\mathrm{Y}=\alpha+\mathrm{bX}$ which can be seen in table 2 below.

Table 2. Simple Linear Regression Equations

\begin{tabular}{cc}
\hline Model & Unstandardized Coefficients \\
\hline & $\mathrm{B}$ \\
1 (Constant) &,- 970 \\
active learning & 1,072 \\
\hline
\end{tabular}

\section{Dependent Variable: concept understanding test} $1.072 \mathrm{X}$.

Based on the analysis that has been done, the regression equation is obtained with a value of $\mathrm{Y}=-, 970+$

The second step of regression testing is to determine the regression significance test. This test step is carried out to find out whether the regression is linear or not. The testing steps are as follows.

Determine the hypothesis

Ho $=$ nonlinear regression

$\mathrm{Ha}=$ linear regression

The significance level is $5 \%$ by testing the hypothesis if sig> 0.05 , then Ho is accepted Ha is rejected. The results of the regression significance test analysis are as follows.

Table 3. ANOVA

\begin{tabular}{cccc}
\hline Model & Sig. & $\boldsymbol{\alpha}$ & Conclusion \\
\hline 1 Regression &, $000^{\mathrm{b}}$ & 0,05 & Ho was rejected, Ha accepted \\
\hline
\end{tabular}

Based on the data analysis, it was obtained that the sig value of 0.000 , this value is smaller than the value of $\alpha$, namely 0.05 . Because the sig value is $<0.05$, then Ho is rejected, and Ha is accepted. Which means that the regression model is linear.

In testing the regression, the third step is to determine the significance test of the regression equation coefficient. This test is used to determine whether the data is consistent or not and to determine whether or not learning activeness has a positive effect on the ability to understand concepts. The steps are as follows.

Determine the hypothesis

Ho $=$ constant $\mathrm{a}$ is not significant

Ho $=$ constant $\mathrm{a}$ is significant.

Ho $=$ active learning does not have a positive effect on the ability to understand concepts

$\mathrm{Ha}=$ active learning has a positive effect on the ability to understand concepts.

The significance level is $5 \%$ with the testing criteria.If the sig value is $>0.05$, then Ho is accepted and Ha is rejected. The results of the analysis of the significance test of the regression equation coefficient are as follows

Table 4. Coefficients ${ }^{\mathrm{a}}$

\begin{tabular}{cccc}
\hline Model & Sig. & $\boldsymbol{\alpha}$ & Conclusion \\
\hline 1 (Constant) &, 907 & 0,05 & Ho was rejected, Ha accepted \\
active learning &, 000 & 0,05 & Ho was rejected, Ha accepted \\
\hline
\end{tabular}

\section{Dependent Variable: concept understanding test}

Based on data analysis, the constant a with a sig value of 0.907 is more than the value of $\alpha$, namely 0.05 . Therefore, Ho is accepted and Ha is rejected. It means that the constant a is not significant. Meanwhile, the learning activity obtained the sig value of 0.000 . This value is less than the value of $\alpha$, namely 0.05 . So, Ho is rejected and $\mathrm{Ha}$ is accepted. It means that active mathematics learning has a positive effect on the ability to understand mathematical concepts.

The fourth step in regression testing is to determine the correlation coefficient and test the significance of the correlation coefficient. This correlation coefficient test is to find out how much the correlation value is. The results are shown in table 5. 
Tabel 5. Correlations

\begin{tabular}{cccc}
\hline & $\begin{array}{c}\text { concept } \\
\text { understanding } \\
\text { test }\end{array}$ & active learning \\
\hline Pearson Correlation & concept understanding test & 1,000 &, 836 \\
& active learning &, 836 & 1,000 \\
\hline
\end{tabular}

The results of the SPSS test showed that the Correlation Coefficient was 0.836. This value is included in the strong category. Meanwhile, the significance test of the correlation coefficient was conducted to determine whether or not the relationship between learning activeness and the ability to understand mathematical concepts was significant. There is a test step for the significance of the correlation coefficient as follows.

Determine the hypothesis

Ho $=$ there is no significant relationship

$\mathrm{Ha}=$ there is a significant relationship.

The significance level is $5 \%$ with the testing criteria if the sig value $>0.05$, then Ho is accepted and Ha is rejected. The results of the analysis of the significance test of the correlation coefficient are as follows:

Tabel 6. Coefficients ${ }^{\mathrm{a}}$

\begin{tabular}{cccc}
\hline Model & Sig. & $\alpha$ & Conclusion \\
\hline active learning &, 000 & 0,05 & $\begin{array}{c}\text { Ho was rejected, Ha } \\
\text { accepted }\end{array}$ \\
\hline
\end{tabular}

\section{Dependent Variable: tespemahamankonsep}

Based on the analysis, it was found that the sig value of 0,000 was smaller than the value of $\alpha$, namely 0.05 . So, Ho is rejected and $\mathrm{Ha}$ is accepted, which means that there is a significant relationship between learning activeness and the ability to understand concepts.

The final step in regression testing is determining the coefficient of determination. Testing the coefficient of determination aims to determine how much the percentage of the effect of learning activeness on the ability to understand concepts using discovery learning models. The results of the analysis of the coefficient of determination test are as follows.

Tabel 7Model Summary

\begin{tabular}{ccc}
\hline Model & R Square \\
\hline 1 &, 698 \\
\hline
\end{tabular}

\section{Predictors: (Constant), active learning}

. The results of the analysis in table 7 show that the R Square value is $0.698=69.8 \%$, which is included in the strong criteria. This shows that the results of the ability to understand mathematical concepts are affected by learning activeness using the Discovery Learning model by $69.8 \%$ while the remaining $30.2 \%$ is determined by other factors.

Based on the data analysis that has been done, learning activeness has a positive and significant effect of $69.8 \%$ on the ability to understand concepts using the Discovery Learning model. The success in increasing student learning activeness cannot be separated from the selection of the right model. The model chosen is the Discovery Learning model, where this model provides student activity during the learning process. The use of the Discovery Learning model is a learning model that is student-oriented, which means that students follow each Discovery Learning process actively from identifying problems to drawing conclusions with the aim of students getting direct learning experiences and getting new knowledge from each learning process that they have been through (Haeruman, L. D.; Rahayu, W. Ambarwati, 2017). The Discovery Learning model is a learning model that places the teacher as a facilitator, where students discover for themselves knowledge they do not know, guided by questions from the teacher, worksheets, and LKK (Mawaddah \& Maryati, 2016). The use of the Discovery Learning model has many advantages, one of which is helping students to strengthen and increase their self-confidence with the self-discovery process and the strategy is student-centered not the teacher one (Roestiyah, 2008). The Discovery Learning model considers the student-centered learning process is because students are asked to learn independently and be active in concept discovery. If students are active in learning, 
students have the courage to express their opinions and students must have the courage to answer questions given by the teacher. The advantage of implementing the Discovery Learning model is that it helps students to improveskills, the knowledge gained is easy to remember, the learning process is fun and student-centered learning lets students be active in pouring ideas or thought (Ratnadewi \& Arini, 2018). The use of discovery learning models can improve learning outcomes and increase student learning activeness(Ma'ruf et al., 2019). In addition to applying the right model of learning activeness, it also depends on the role of the teacher in creating a comfortable classroom atmosphere so that students are active in learning mathematics. Learning activeness when combined with the role of the teacher as the right facilitator will result in successful learning according to the objectives (Kristian, 2017).

During the learning process, students are very enthusiastic in participating because the appropriate model and role of the teacher is applied so that students become active in learning. Students dare to ask or answer when they do not understand the material presented by the teacher so that the learning process is successful with reciprocal interactions between students and teachers. After being taught using the model, it yielded results with increasing student learning activeness affecting the understanding obtained by students. Activeness in learning is very influential on student achievement, because active learning is able to bring out the students' mental, physical or psychological condition. Students who are active during their learning process will dare to ask questions if they get material that is not clear or students dare to answer questions given by the teacher so that children understand the material they are learning. One of the success factors in learning activeness is giving motivation and the applied learning style. The right learning style will affect student learning activeness, because a fun learning style makes students feel confident in the learning process so that students will not feel afraid to ask or answer questions from the teacher (Ulya, H.; Rahayu, 2020). The use of learning styles can increase student activity based on five indicators, including attention, cooperation and social relations, expressing opinions or ideas, solutions and discipline(Wibowo, 2016). Learning activeness is the most important component in the learning process. Activeness is a learning process in which the teacher must create an atmosphere in such a way that students can actively ask questions, be able to put forward ideas, and seek for the data and information they need to solve problems(Rahayu \& Hardini, 2019). Student activeness is very important because activity can foster a good mentality for students. Students are considered to be active if they have the following characteristics, including students dare to answer questions from the teacher, be able to ask the teacher when students do not understand the material given, and be able to do assignments according to the given time or on time. With active learning in the classroom, it makes learning more vivid and enjoyable so that the reciprocal relationship between students and teachers runs smoothly. This reciprocal relationship will increase the students' ability to understand mathematical concepts regarding the volume of blocks and cubes being taught by the teacher. Active learning is an effort made by the teacher to allow students carry out activities freely both physically and spiritually, not be afraid to argue or answer, and be able to solve problems independently and have a maximum reciprocal relationship with the teacher(Muah, 2016). If students are able to be active in every lesson, students are able to master the material taught well which results a positive effect on learning outcomes.

From the above results, it is found that learning activeness has a positive effect on students' conceptual understanding abilities using discovery learning models. Learning activeness has a significant effect on learning outcomes(Kayaman, 2015).Student learning activeness affects students' mathematical abilities(Trisnawati et al., 2019). In line with the research that has been done by (Ulia \& Sari, 2018) which argues that activeness in the learning process can affect the value of understanding mathematical concepts.

The research that has been done is an experiment in which the results obtained can be used as a reference for selecting a learning model to improve student achievement. In addition, this research is expected to reduce problems that occur in the world of education. The results shows positive effect on all parties concerned. One of the positive impacts is the application of the discovery learning model to make students become active when learning mathematics, with the activeness obtained by students making students' conceptual understanding skills increase. In short, it can be interpreted that learning activeness has a great influence on students' conceptual understanding ability. It is revealed from the results, a positive influence on student learning by applying the discovery learning model, because this model is able to strengthen students' activeness in the mathematics learning process. Therefore, in the different character of students, they must be careful in choosing the learning model to be applied to students because they must know the positive and negative impacts.

\section{Conclusion}

From the results of the research that has been conducted, it is concluded that learning activeness has a positive and significant effect of $69.8 \%$ on the ability to understand concepts using the Discovery Learning model. Which means, the higher the learning activity, the higher the results of students' understanding of mathematical concepts. Based on these results, it is suggested that educators apply the Discovery Learning model in learning mathematics. It has been proven in this study that by implementing Discovery Learning, 
improving student learning activity will also have a positive impact on their ability to understand mathematical concepts.

\section{References}

Cahyo, A. N. (2013). Panduan Aplikasi Teori-Teori Belajar Mengajar. Diva Press.

Duwit, M. (2016). Pengaruh Fasilitas Belajar Dan Keaktifan Belajar Siswa Terhadap Hasil Belajar Pada Materi Jamur Siswa Kelas X SMA YPK Teminabuan Kabupaten Sorong Selatan. Jurnal Ilmu Pendidikan Indonesia, 4(2), 49-56.

Febriyanto, B., Haryanti, D. Y., \& Komalasari, O. (2018). Peningkatan Pemahaman Konsep Matematis Melalui Penggunaan Media Kantong Bergambar Pada Materi Perkalian Bilangan Dikelas II Sekolah Dasar. Jurnal Cakrawala Pendas, 4(2), 32-44.

Haeruman, L. D.; Rahayu, W. Ambarwati, L. (2017). No Title. Jurnal Penelitian Dan Pembelajaran Matematika (JPPM), 10(2), 157-168.

Hambalik, O. (2015). Kurikulum dan Pembelajaran. PT Bumi Aksara.

Hendriana, H., Rohaeti, E. E., \& Sumarmo, U. (2017). Hard Skills dan Soft Skills Matematik Siswa. PT Refika Aditama.

Jayadiningrat, M. G., Putra, K. A. A., \& Putra, P. S. E. A. (2019). Penerapan Model Pembelajaran Discovery Learning Untuk Meningkatkan Aktivitas Dan Hasil Belajar Siswa Siswa. Jurnal Pendidikan Kimia Undiksha, 3(2), 83-89.

Junitasari, \& Hayati, F. (2019). Analisis Kemampuan Pemahaman Konsep Matematis Siswa SMP Pada Materi Kubus Dan Balok. Mathematics Educations Journal, 2(1), 14-25.

Kayaman. (2015). Pengaruh Metode Eksperimen, Motivasi dan Keaktifan Belajar terhadap Hasil Belajar pada Pokok Gerak Lurus pada Siswa SMA Negeri 1 Aimas Kabupaten Sorong. Jurnal Ilmu Pendidikan Indonesia, 3(3), 44-53.

Kristian, F. (2017). Keberhasilan Belajar Mahasiswa Ditinjau dari Keaktifan Dalam Perkuliahan dengan Menggunakan Pembelajaran Active Learning. Jurnal Pendidikan Dasar Perkhasa, 3(2), 405-413.

Lestari, K. E., \& Yudhanegara, M. R. (2015). Penelitian Pendidikan Matematika. PT Refika Aditama.

Ma'ruf, M. I., Kristian, F., \& Anugraheni, I. (2019). Penerapan Model Pembelajaran Discovery Learning untuk Meningkatkan Keaktifan dan Hasil Belajar Siswa Kelas 4. Jurnal Basicedu, 3(2), 306-312.

Maulida, A. H., Ningsih, M. F., \& Bastian, T. (2018). Pengaruh Model Discovery Learning terhadap Kemampuan Komunikasi Matematis dan Keaktifan Belajar Siswa SMP. Jurnal Ilmiah Pendidikan Matematika, 6(1), 47-52.

Mawaddah, S., \& Maryati, R. (2016). Kemampuan Pemahaman Konsep Matematis Siswa SMP dalam Pembelajaran Menggunakan Model Terbimbing (Discovery Learning). Jurnal Pendidikan Matematika, 4(1), 76-85.

Muah, T. (2016). Penggunaan Model Pembelajaran Problem Based Instruction (PBI) untuk Meningkatkan Keaktifan dan Hasil Belajar Matematika Siswa Kelas 9B Semester Gasal Tahun Pelajaran 2014/2015 SMP Negeri 2 Tuntang-Semarang. Jurnal Scholaria, 6(1), 41-45.

Putra., Darma, I. G., Sujana, I. W., \& Wijaya, I. K. N. (2020). Hasil Belajar IPS Menggunakan Kolaborasi Model Discovery Learning Berbasis Media Animasi. Journal of Education Technology, 4(2), 103-109.

Putri, E. N. (2018). Peningkatan Keaktifan Belajar dan Hasil Belajar melalui Model Pembelajaran Discovery Learning. Jurnal Pendidikan Ke-SD-An, 4(2), 369-374.

Rahayu, I. P., \& Hardini, A. T. A. (2019). Penerapan Model Discovery Learning untuk Meningkatkan Keaktifan dan Hasil Belajar. Journal of Education Action Research, 3(3), 193-200.

Rahmayani, A., Siswanto, J., \& Budiman, M. A. (2019). Pengaruh Model Pembelajaran Discovery Learning dengan Menggunakan Media Video terhadap Hasil Belajar. Jurnal Ilmiah Sekolah Dasar, 3(2), 246-253.

Ratnadewi, I. D. A., \& Arini, N. W. (2018). Penerapam Discovery Learning Berbantuan Media Visual untuk Meningkatkan Hasil Belajar IPS. Jurnal Ilmiah Pendidikan Profesi Guru, 1(1), 20-28. 
Roestiyah, N. K. (2008). Strategi Belajar Mengajar. Rineka Cipta.

Samadhi, N. N. N., \& Riastini, P. N. (2017). Pengaruh Pembelajaran Quantum Berbantuan Permainan dalam Pembelajaran terhadap Keaktifan dan Hasil Belajar Kognitif IPA Siswa Kelas V. International Journal Of Elementary Education, 1(3), 228-237.

Sari, N. M. M., Parmiti, D. S., \& Japa, I. G. N. (2017). No Title. E-Jurnal PGSD Universitas Pendidikan Ganesa, 5(2), 1-10.

Sugiyono. (2010). Metode Penelitian Pendidikan Pendekatan kuantitatif, Kualitatif dan R\&D. Alfabeta.

Sumaryati, I., Rahayu, R., \& Utaminingsih, S. (2018). Peningkatan Kemampuan Pemahaman Konsep Matematika Siswa SD melalui Model Guided Discovery Learning Berbantuan Permainan Kaki Bima. ANARGYA: Jurnal Ilmiah Pendidikan https://doi.org/10.24176/anargya.v1i1.2284

Trisnawati, Y. I., Sudargo., \& Dina, P. (2019). Efektivitas Model Contextual Teaching And Learning dan Model Problem Based Learning untuk Meningkatkan Kemampuan Pemahaman Konsep Matematis Siswa SMP. Jurnal Matematika Dan Pendidikan Matematika, 1(5), 190-200.

Triwiyanto, T. (2015). Manajemen Kurikulum dan Pembelajaran. PT Bumi Aksara.

Ulia, N., \& Sari, Y. (2018). Pembelajaran Visual, Auditory dan Kinestetik Terhadap Keaktifan Belajar dan Pemahaman Konsep Matematika Siswa Sekolah Dasar. Jurnal Pendidikan Guru MI, 5(2), 175-190.

Ulya, H.; Rahayu, R. (2020). Kemampuan Representasi Matematis Field Intermediate dalam Menyelesaikan Soal Etnomatematika. Aksioma: Jurnal Program Studi Pendidikan Matematika, 9(2), 451-466.

Wibowo, N. (2016). Peningkatan Keaktifan Siswa melalui Pembelajaran berdasarkan Gaya Belajar di SMK Negeri 1 Saptosari. Jurnal Electronics, Informatics, and Vocational Education, 1(2), 128-139.

Yuliana, N. (2018). Pengunaan Model Pembelajaran Discovery Learning dalam Peningkatan Hasil Belajar Siswa di Sekolah Dasar. Jurnal Ilmiah Pendidikan Dan Pembelajaran PPS Universitas Pendidikan Ganesha, 2(1), 21-28. 